\title{
DISTRIBUTION OF THE PARASITOID, COMPERIELLA LIMINISTACA (HYMENOPTERA: ENCYRTIDAE) IN EGYPT WITH EMPHASIS ON THE EGYPTIAN OASES
}

\author{
SHAABAN ABD-RABOU AND MONA MOSTAFA
}

Plant Protection Research Institute, ARC, Dokki, Giza

(Manuscript received 26 February 2009)

\begin{abstract}
The encyrtid parasitoid, Comperiella lemniscata Compere and Annecke (Hymenoptera: Encyrtidae) which attacks armored scale insects. Samples were collected from different locations in Egypt as well as the Egyptian Oases. Results indicated that the parasitoid, C. lemniscata is recorded in 6 localities of 5 governorates in Egypt. The present work also dealt with the distribution of this species in the Egyptian Oases, results recorded the parasitoid in 7 localities of 4 oases. Maps of the distribution of aforementioned parasitoid were provided.
\end{abstract}

\section{INTRODUCTION}

The encyrtid parasitoid, Comperiella lemniscata Compere and Annecke (Hymenoptera: Encyrtidae) was recorded in Egypt for the first time in Egypt associated with the armored scale insect, Aonidiella aurantii (Maskell) (Homoptera: Diaspididae ) in Giza by Abd-Rabou and Attia. 2006. The parasitoid, C. lemniscata recorded as a parasitoid of armored scale insects (Garonna \& Viggiani, 1993, Noyes and Hayat, 1994, Prinsloo,1996, Abd-Rabou, 2006 and Abd-Rabou and Attia. 2006.

Armored scale insects are considered as serious pests on different orchards and ornamental plants in Egypt ( Abd-Rabou, 1997). The main injury caused by these pests are the ingestion of plant sap. Their damage is manifested in reducing the number of healthy plant. Severely infested plants grow poorly and may drop leaves prematurely and suffer dieback of twigs and branches ( Abd-Rabou, 1999a and b).

The present work deals with the distribution of $C$. lemniscata in Egypt.

\section{MATERIALS AND METHODS}

Collected leaves heavily infested by armored scale insects in different locations in Egypt specially in the Egyptian Oases were transferred to the laboratory for parasitoids emergence and identification. Identification of the parasitoid followed mounting the specimens through the method of Noyes (1982). Maps adopted from www.egyptmyway.com/contactforms.html (2008). 


\section{RESULTS AND DISCUSSION}

\section{Distribution of Comperiella lemniscata in Egypt except oases .}

As shown in Table (1) and Map (1) C. lemniscata is recorded in 6 localities of 5 governorates in Egypt.

Table 1. Distribution of Comperiella lemniscata in Egypt.

\begin{tabular}{|c|c|c|}
\hline \multicolumn{2}{|c|}{ Distribution } & \multirow{2}{*}{ Date of Collection } \\
\cline { 1 - 2 } Governorate & Locations & Sep., 2008 \\
\hline Asyut & El-Badari & Oct.2008 \\
\hline Beni-Suif & El-Wasta & Sep., 2008 \\
\hline Cairo & Helwan & Sep.., 2007 \\
\hline El-Minia & Mallawi & Agu., 2008 \\
\hline Giza & El-Aiyat & July, 2007 \\
\hline
\end{tabular}

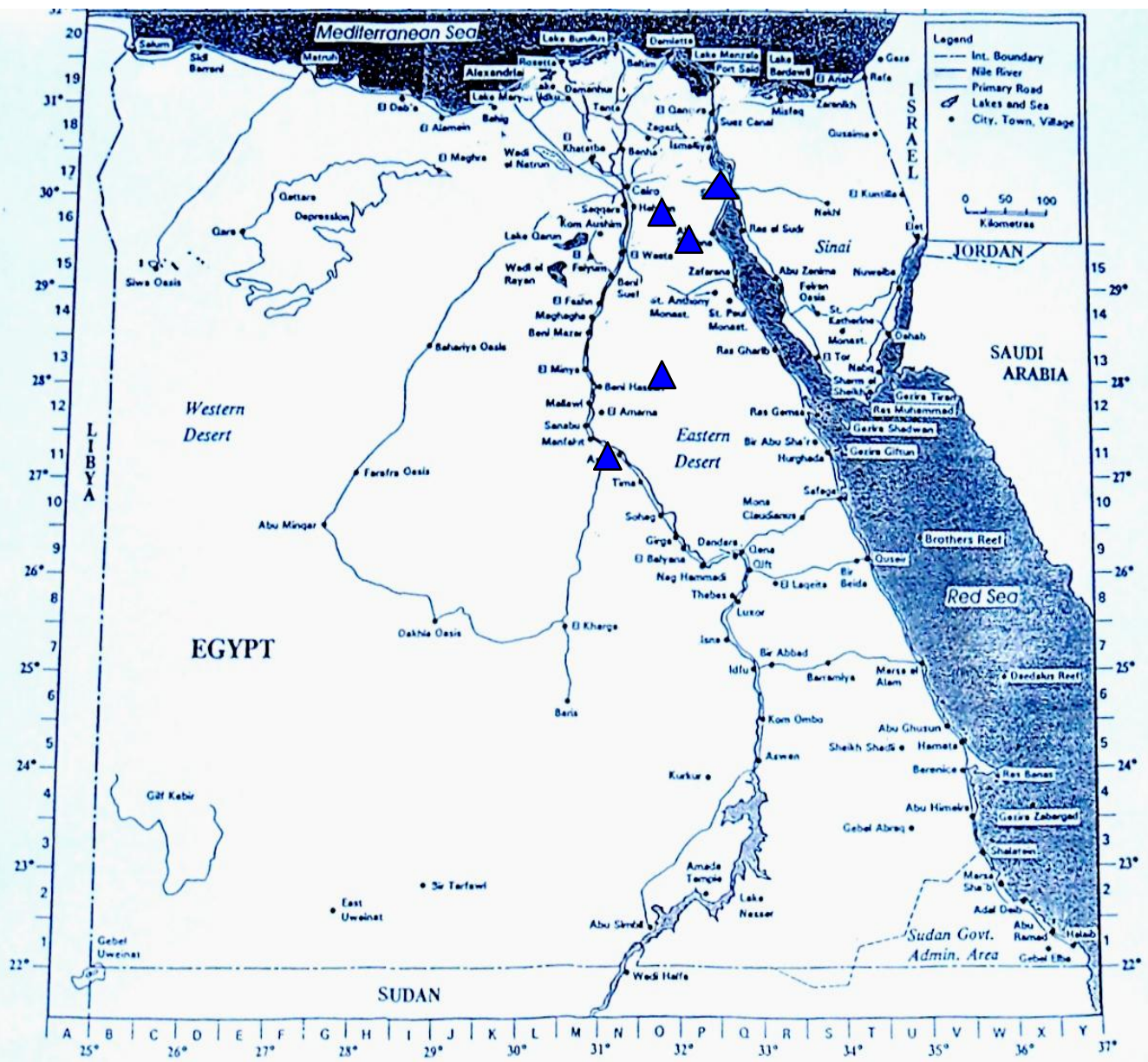

Map 1. Distribution of the parasitoid, Comperiella lemniscata in different localities in Egypt. 


\section{Distribution of Comperiella lemniscata in Egyptian oases .}

As shown in Table (2) and Maps $(2,3,4,5)$ C. lemniscata is recorded in 7 localities of 4 oases in Egyptian oases.

Table 2. Distribution of Comperiella lemniscata in Egyptian oases.

\begin{tabular}{|c|c|c|}
\hline \multicolumn{2}{|c|}{ Distribution } & \multirow{2}{*}{ Date of Collection } \\
\hline Oasis & Locations & July, 2008 \\
\hline Baharia & Bawiti & Oct. 2008 \\
\hline Dakhla & Bir Ziyat & Oct. 2008 \\
\hline & Gedida & Oct. 2008 \\
\hline Farafra & Mut & Sept.2008 \\
\hline Kharga & Bir Sitta & Oct. 2008 \\
\hline & Qasr & Oct. 2008 \\
\hline
\end{tabular}

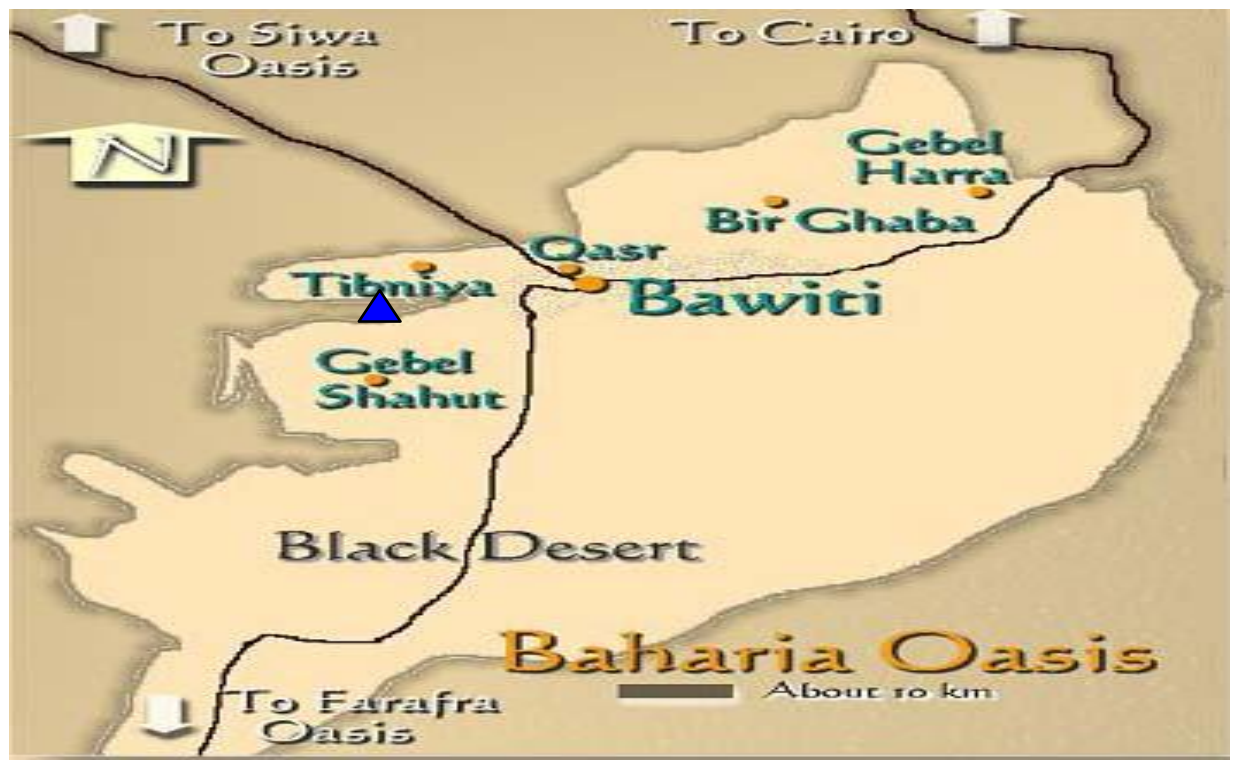

Map 2. Distribution of the parasitoid, Comperiella lemniscata in Baharia Oasis 


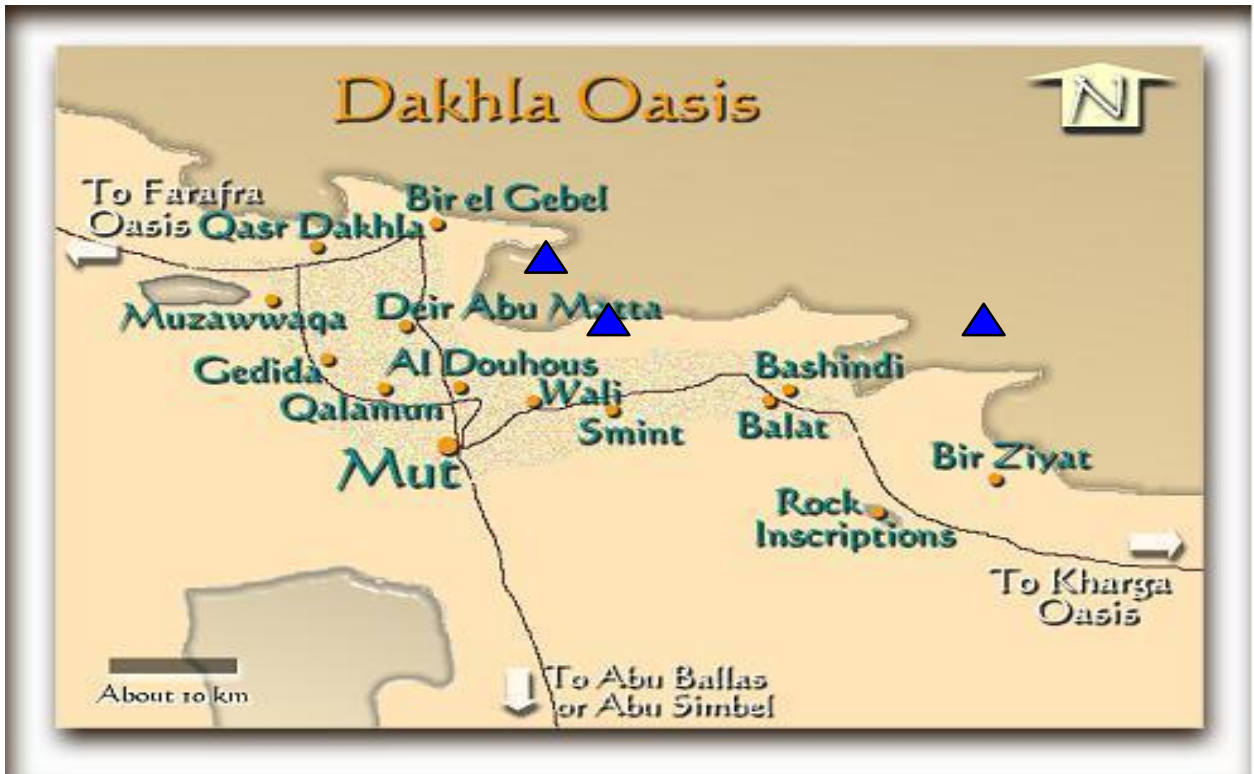

Map 3 . Distribution of the parasitoid, Comperiella lemniscata in Dakhla Oasis

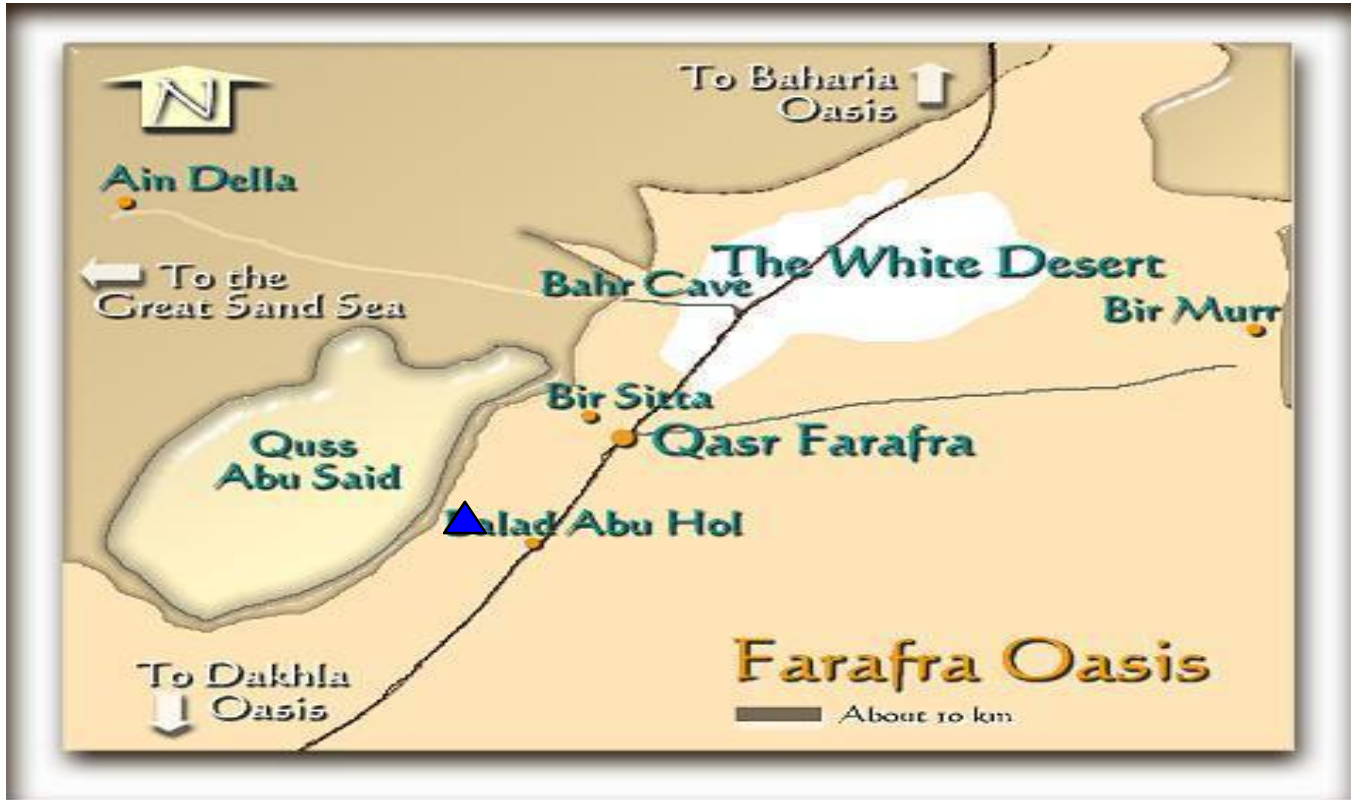

Map 4 Distribution of the parasitoid, Comperiella lemniscata in Farafra Oasis 


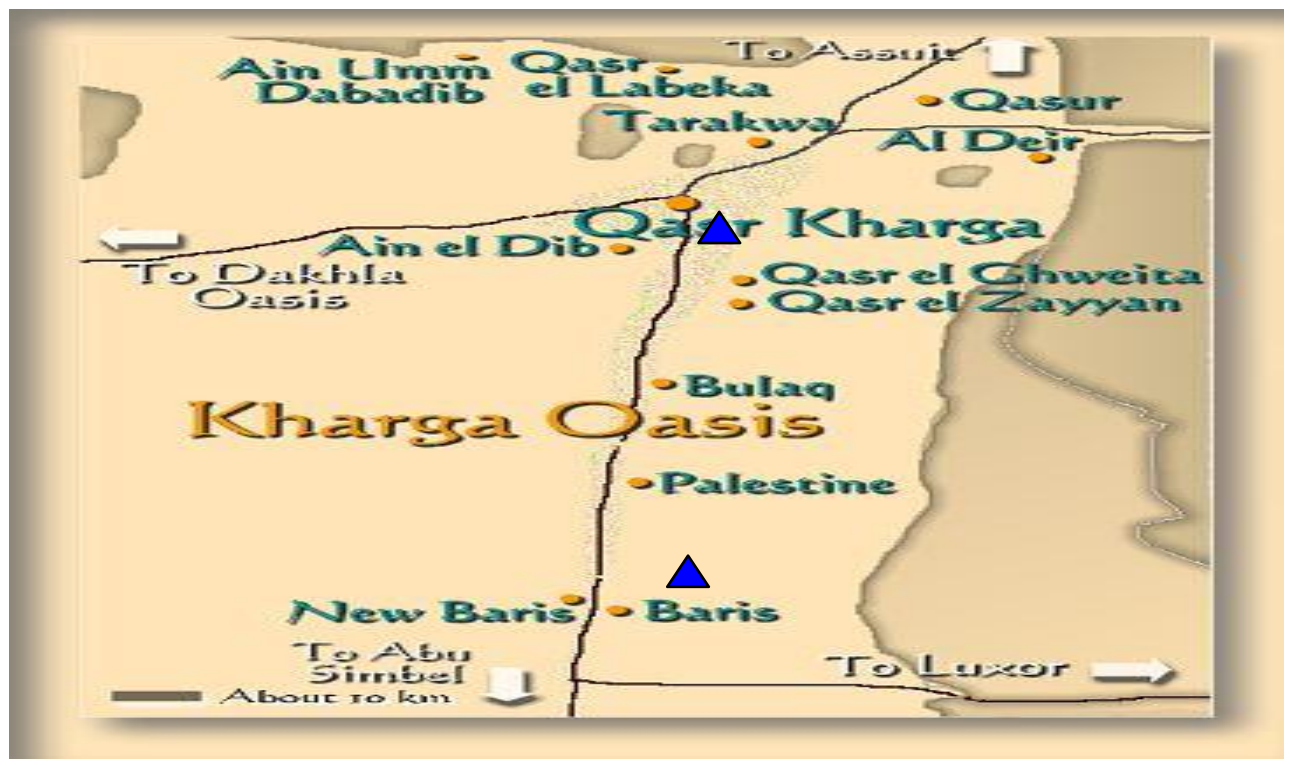

Map 5 . Distribution of the parasitoid, Comperiella lemniscata in Kharga Oasis

\section{REFERENCES}

1. Abd-Rabou, S. 1997. Parasitoids attacking some species of scale insects (Homoptera: Coccoidea: Diaspididae) in Egypt. Proceeding of the First Scientific Conference of Agricultural Sciences, Faculty of Agric. Assiut Univ., Vol. II, 727736

2. Abd-Rabou, S. 1999a. Parasitoids attacking the Egyptian species of armored scale insects (Homoptera : Diaspipidae). Egypt J. Agric. Res., 77(3): 1113-1129.

3. Abd-Rabou, S. 1999b. An annotated list of diaspidid parasitoids in Egypt. Entomolgica, Bari, 33: 173-177.

4. Abd-Rabou, S. 2006. Hymenopterous parasitoids as a bioagent for controlling homopterous insects in Egypt. Egypt. Adv. Agric. Res. In Egypt, Vol. (6) 1: 1-65.

5. Abd-Rabou S. and A. R. Attia. 2006. New record of the parasitoid, Comperiella lemniscata Compere and Annecke (Hymenoptera: Encyrtidae) on Aonidiella aurantii (Homoptera: Diaspididae) on guava in Egypt. Egypt. J. Agric.Res.84 (1): 83-87.

6. Garonna, A.P. and G. Viggiani. 1993. Uleriori osservazioni morfo-biologiche di laboratorio su Comperiella lemniscata Compere \&Annecke (Hymenoptera : Encyrtidae), parassitoide endofago di Chrysomphalus dictyospermi (Morgan) (Homoptera: Diaspididae). Bollettino del Laboratorio di Entomologia Agraria ' Filippo Silvestri' , 48:117-124. 
7. Noyes, J. S. 1982. Collecting and preserving chalcidid wasps (Hymenoptera : Chalcidoidea). Journal of Natural History, 16: 315-334.

8. Noyes, J. S. and M. Hayat. 1994. Oriental mealybug parasitoids of the Anagyrini (Hymenoptera: Encyrtidae). C.A.B. International, Wallingford.

9. Prinsloo, G. L. 1996. The genus Comperiella (Hymenoptera : Encyrtidae) in southern Africa: parasitoids of armoured scale insects ( Homoptera : Diaspididae). African Entomology, 4(2): 153-160.

10. Web site. 2008. www.egyptmyway.com/contactforms.html 
التوزيع الجغرافى لطفيل الكومبيريلا ليمينيستاكا فى مصر مع التركيز على تواجده فى مناطق الواحات المصرية

شعبان عبد ربه و منى مصطفى

معرد بحوث وقاية النباتات - مركز البحوث الزراعية - الدقي - جيزة-

ي عد طفيل الكومبيريلا ليمينيستاكا من الطفيليات المهمة فى مكافحة الحشرات القشرية

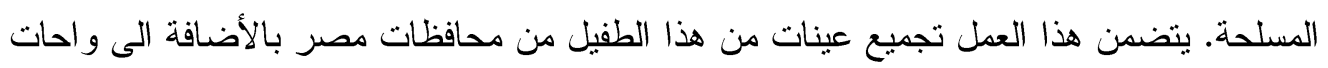

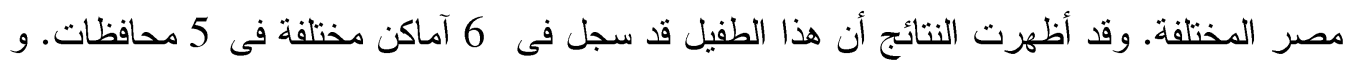

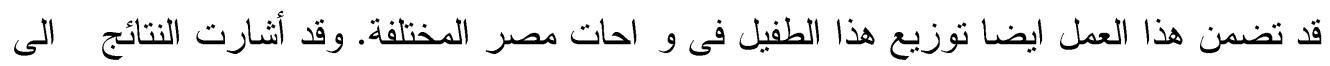

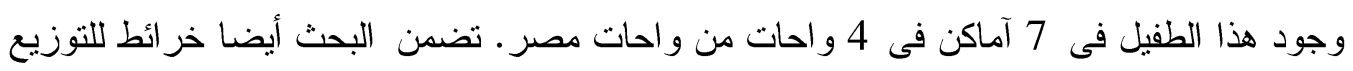
الجغر افى لهذا الطفيل فى محافظات وواحات مصر المختلفة 